\title{
Management of the Artificial Airway
}

\author{
Richard D Branson MSc RRT FAARC, Dina Gomaa RRT, and \\ Dario Rodriquez Jr MSc RRT FAARC
}

\author{
Introduction \\ Securing the Airway \\ Literature Review \\ Maintaining Airway Patency \\ Humidification \\ Heated Humidification Versus Heat-and-Moisture Exchangers for \\ Humidification and Secretion Management \\ Maintaining the Endotracheal Tube Lumen \\ Suctioning \\ Open Versus Closed Suctioning \\ Bronchial Suctioning \\ Deep Versus Shallow Suctioning \\ Use of Saline Instillation \\ When to Suction \\ Novel Methods for Secretion Removal From the Endotracheal Tube \\ Mucus Slurper \\ Mucus Shaver \\ Biofilm Prevention \\ Monitoring Endotracheal Tube Position and Patency \\ Rescuing the Endotracheal Tube \\ Cuff Pressure Management \\ Summary
}

\begin{abstract}
Management of the artificial airway includes securing the tube to prevent dislodgement or migration as well as removal of secretions. Preventive measures include adequate humidification and appropriate airway suctioning. Monitoring airway patency and removing obstruction are potentially life-saving components of airway management. Cuff pressure management is important for preventing aspiration and mucosal damage as well as assuring adequate ventilation. A number of new monitoring techniques have been introduced, and automated cuff pressure control is becoming more common. The respiratory therapist should be adept with all these devices and understand the appropriate application and management. Key words: Artificial airway; mechanical ventilation; humidification. [Respir Care 2014;59(6):974-990. (C) 2014 Daedalus Enterprises]
\end{abstract}

The authors are affiliated with the Department of Surgery, University of Cincinnati, Cincinnati, Ohio.

Mr Branson presented a version of this paper at the 52nd RESPIRATORY CARE Journal Conference, "Adult Artificial Airways and Airway Adjuncts" held June 14 and 15, 2013, in St Petersburg, Florida.

Mr Branson has relationships with Ikaria, Bayer, Hamilton Medical,
Covidien, and Advanced Circulatory Systems. The other authors have disclosed no conflicts of interest.

Correspondence: Richard D Branson MSc RRT FAARC, Department of Surgery, University of Cincinnati, 231 Albert Sabin Way, Suite 1571, Cincinnati, OH 45267-0558. E-mail: richard.branson@uc.edu.

DOI: $10.4187 /$ respcare. 03246 


\section{Introduction}

Management of the artificial airway is one of the core competencies of the bedside respiratory therapist. Airway management includes securing the tracheal tube, monitoring tube position, maintaining patency, and appropriate regulation of cuff pressure. There are a number of methods for securing tubes from simple adhesive tape to more complex devices that combine bite block, a method for moving the tube to prevent skin breakdown and mucosal ulceration, and a fixation system. Maintaining airway patency includes routine treatments, such as humidification of inspired gases and suctioning, as well as techniques to reduce biofilm or clear obstruction. Monitoring cuff pressure is a time-honored activity to maintain a balance between adequate lower airway protection from silent aspiration and minimizing mucosal damage. Automated cuff pressure management is a new method to achieve this result that is gaining popularity.

Each of these techniques is reviewed in detail below, with an emphasis on new science and new techniques introduced since a comprehensive review on a number of these subjects in $2007 .{ }^{1}$

\section{Securing the Airway}

Following placement of an artificial airway, securing the tube to prevent accidental removal or unintended migration is recommended. ${ }^{2}$ Both unplanned extubation and right main bronchus intubation have severe consequences, including barotrauma, aspiration, airway injury, and death. ${ }^{3}$ As a result, early homemade securing techniques included adhesive tape and occasionally sutures in an effort to assure placement. Commercially available devices now use Velcro, adjustable straps, bite blocks, barrier materials to protect skin, and adjustable tube-positioning devices.

Competing with the interests of tube security are concerns related to pressure sores and mucosal injury from prolonged placement. ${ }^{4}$ This concern has been highlighted by The Joint Commission's national patient safety goal of pressure ulcer prevention. ${ }^{5}$

Ideally, an endotracheal tube (ETT)-securing device is easy to clean and allows for easy repositioning of the tube in the mouth to reduce pressure sores and prevent dislodgement. Figure 1 depicts a common commercially available ETT-securing device in a mechanically ventilated patient.

\section{Literature Review}

In an early study, Levy and Griego ${ }^{6}$ compared adhesive tape, twill tape, twill tape with a bite block, and a Velcro tie and bite block on sequential days in 36 mechanically ventilated subjects. Twill tape is a cloth tape often called

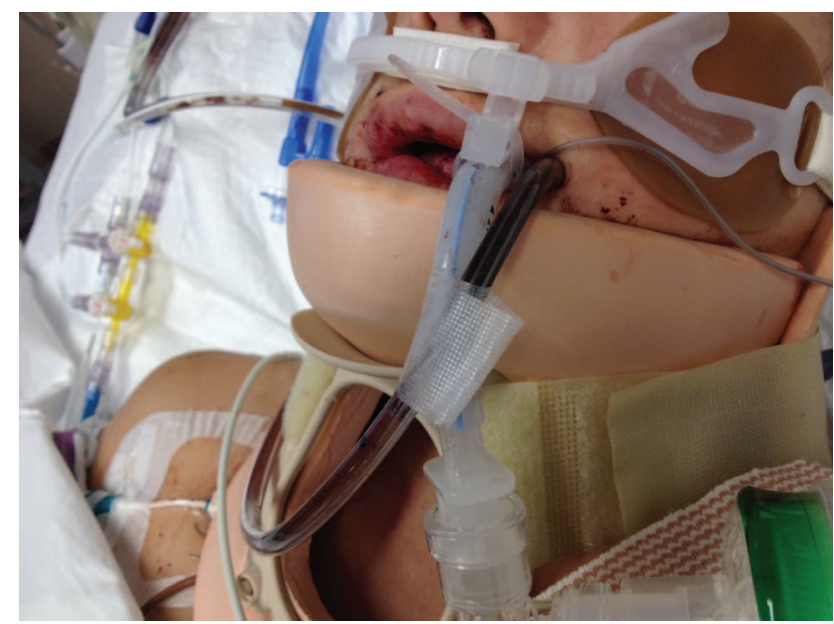

Fig. 1. Picture of a commercially available endotracheal tube holder in an orally intubated patient.

trach tape in many environments. The authors compiled results from a 5-point Likert scale regarding oral hygiene, subject comfort, clinician satisfaction, and ease of use completed by the bedside nurse, respiratory therapist, and, when feasible, subject. Position of the tube at the incisor at the end of each shift was documented, and the incidence of near extubations was recorded. The authors found that adhesive tape was superior to all other methods in every area except oral hygiene. The use of a flexible bite block was associated with excess tube movement and increased risk of extubation.

Kaplow and Bookbinder ${ }^{7}$ compared 4 methods of securing the ETT, including the Lillehei harness, Comfit (Ackrad Laboratories, Cranford, New Jersey), Dale (Dale Medical Products, Plainville, Massachusetts), and SecureEasy (Smiths Medical, Dublin, Ohio) devices, in 120 orally intubated subjects evaluated every $12 \mathrm{~h}$. The outcome variables were tube stability, facial skin integrity, and subject and caregiver satisfaction. The authors reported that facial skin breakdown occurred less frequently with the SecureEasy and Dale holders. Subject complaints regarding discomfort with turning were least common with the Lillehei harness. The SecureEasy device was associated with the highest degree of nurse satisfaction.

Barnason et $\mathrm{al}^{8}$ compared the Lillehei method and cotton twill using a cow hitch knot in a group of orally intubated subjects. The authors evaluated the incidence of unplanned extubation, oral mucosa status, and facial skin integrity. The study did not detect any difference between the 2 techniques, but it is interesting to note that the overall unplanned extubation rate in this trial was $19 \%$.

A systematic review by Gardner et al in $2005^{9}$ concluded that research to date could not identify any method for securing the ETT that was superior. However, this study can be credited for highlighting the limitations in the literature to this point. 
Table 1. Studies Comparing ETT-securing Devices in Cadavers or Models

\begin{tabular}{|c|c|c|c|c|}
\hline Study & Model & Devices Tested & Force Generation & Results \\
\hline Lovett et al ${ }^{10}$ & $\begin{array}{l}\text { Mannequin, PVC } \\
\text { tube to simulate } \\
\text { trachea }\end{array}$ & $\begin{array}{l}\text { Comfit (Ackrad) } \\
\text { StabilTube (B\&B Medical } \\
\text { Technologies) } \\
\text { Tube restraint (ErgoMed) } \\
\text { ETAD (Hollister) } \\
\text { Thomas ST (STI Medical } \\
\text { Products) } \\
\text { Dale ETT holder }\end{array}$ & $\begin{array}{l}\text { Cable-and-pulley system with } \\
\text { weight producing a dynamic } \\
\text { load or jerk of } 2.5 \text { and } 5 \text { pounds }\end{array}$ & $\begin{array}{l}\text { ETT movement was measured. } \\
\text { The Dale device was } \\
\text { superior to other devices } \\
\text { tested. }\end{array}$ \\
\hline $\begin{array}{l}\text { Murdoch and } \\
\text { Holdgate }^{11}\end{array}$ & Mannequin & $\begin{array}{l}\text { Cloth tape } \\
\text { Thomas ETT holder } \\
\text { (Laerdal) }\end{array}$ & $\begin{array}{l}\text { Fixed force laterally and to the } \\
\text { right by dropping a } 1.25-\mathrm{kg} \\
\text { weight a distance of } 50 \mathrm{~cm}\end{array}$ & $\begin{array}{l}\text { ETT movement was measured. } \\
\text { Tube movement was } \\
\text { significantly less with the } \\
\text { ETT holder ( } 22 \text { vs } 4 \mathrm{~mm} \text { ). }\end{array}$ \\
\hline Carlson et al ${ }^{12}$ & Cadavers & $\begin{array}{l}\text { Adhesive tape } \\
\text { EndoGrip (BioMedix) } \\
\text { Precision Medical ETT } \\
\quad \text { holder (Teleflex) } \\
\text { Tube Tamer (ErgoMed) } \\
\text { Thomas ETT holder } \\
\text { (Laerdal) }\end{array}$ & $\begin{array}{l}\text { Manually by grasping the digital } \\
\text { force-measuring device and } \\
\text { gradually pulling the ETT } \\
\text { vertically, perpendicular to the } \\
\text { cadaver; gradual force with } \\
\text { no jerking }\end{array}$ & $\begin{array}{l}\text { The Thomas ETT holder was } \\
\text { the superior device, } \\
\text { followed by adhesive tape. }\end{array}$ \\
\hline Owen et $\mathrm{a}^{13}$ & Cadavers & $\begin{array}{l}\text { Adhesive tape } \\
\text { Nonadhesive tape } \\
\text { Thomas ETT holder } \\
\text { (Laerdal) }\end{array}$ & $\begin{array}{l}\text { Manual application of gradually } \\
\text { escalating force perpendicular to } \\
\text { the cadaver's face; force } \\
\text { measurement }\end{array}$ & $\begin{array}{l}\text { The Thomas ETT holder was } \\
\text { superior to the other } \\
\text { methods. }\end{array}$ \\
\hline Carlson et al ${ }^{14}$ & Cadavers & $\begin{array}{l}\text { Alternative airway devices } \\
\text { Esophageal combitube } \\
\text { King laryngeal tube } \\
\text { Laryngeal mask airway }\end{array}$ & $\begin{array}{l}\text { Manual traction vertical to the } \\
\text { cadaver using a digital force } \\
\text { meter up to } 28 \text { pounds }\end{array}$ & $\begin{array}{l}\text { The device with the largest } \\
\text { volume cuff was the most } \\
\text { difficult to dislodge. }\end{array}$ \\
\hline Farbod et al ${ }^{15}$ & Cadavers & $\begin{array}{l}\text { Adhesive tape } \\
\text { Suture } \\
\text { Adhesive tape and suture }\end{array}$ & $\begin{array}{l}\text { Progressively increasing weight up } \\
\text { to } 20 \text { pounds }\end{array}$ & $\begin{array}{l}\text { Suture through tape and skin } \\
\text { was superior. }\end{array}$ \\
\hline $\begin{array}{l}\mathrm{ETT}=\text { endotrache } \\
\mathrm{ETAD}=\mathrm{ETT} \text { atta }\end{array}$ & & & & \\
\hline
\end{tabular}

A series of studies have been published evaluating the ability of devices to maintain tube position in the face of calibrated force in models or cadavers. ${ }^{10-15}$ These investigations used a myriad of devices from tape to commercially available complex devices along with a variety of techniques to simulate a force to potentially dislodge the tube. These studies are detailed in Table 1.

Kupas et al ${ }^{16}$ performed a prospective, observational, multi-center study at 42 emergency medical service agencies to evaluate the incidence of unintended tube dislodgement with different securing methods. Over a period of 18 months, they studied 1,732 successful and unsuccessful airway placements where the tube was secured in some way. Methods of securing the tubes in this study included the use of adhesive tape, tape wrapped around the neck, woven twill or umbilical tape, intravenous or oxygen tubing, commercial tube holders, and manual stabilization/none. They also recorded the concurrent use of a cervical collar and/or cervical immobilization device.
Dislodgement of the ETT occurred in 51 (2.9\%) intubations. Factors associated with tube dislodgement included the use of manual stabilization and subject age $<5$ y old. Interestingly, no subject using cloth (twill tape) suffered a tube dislodgment. The other methods all had similar rates of dislodgement (2.3-4.5\%).

Two recent papers published in RESPIRATORY CARE have evaluated a number of new devices in a laboratory setting. ${ }^{17,18}$ Shimizu et al ${ }^{17}$ used a mannequin (SimMan, Laerdal, Wappingers Falls, New York) orally intubated with the tube affixed using tape and a number of commercially available devices. The authors tested 3 brands of tape (Durapore [3M, St Paul, Minnesota], Multipore Dry [3M], and Wardel [Taketora Holdings, Tokyo, Japan]) with 6 methods, and 2 commercially available ETT holders (LockTite [B\&B Medical Technologies, Carlsbad, California] and Thomas [Laerdal]) with one method. They also tested a Universal Bite Block (B\&B Medical Technologies, Carlsbad, California) using 2 methods of securing the tube. 
Table 2. Advantages and Disadvantages of Methods of ETT Stabilization

\begin{tabular}{|c|c|c|}
\hline ETT Stabilization & Advantages & Disadvantages \\
\hline $\begin{array}{l}\text { Adhesive tape, cotton ties (twill } \\
\text { tape, trach tape) }\end{array}$ & $\begin{array}{l}\text { Custom-fit to each patient } \\
\text { Reduced pressure ulcer formation } \\
\text { Avoidance of tube movement (extubation) } \\
\text { Inexpensive } \\
\text { Comfort }\end{array}$ & $\begin{array}{l}\text { Soils easily, cannot be cleaned, must be replaced } \\
\text { May require frequent replacement } \\
\text { Skin sensitivity to adhesives } \\
\text { Difficult in patients with facial hair } \\
\text { Difficult to change tube position }\end{array}$ \\
\hline $\begin{array}{l}\text { Commercially available ETT } \\
\text { holders }\end{array}$ & $\begin{array}{l}\text { Facilitates/speeds movement of tube in oral cavity } \\
\text { Can be cleaned } \\
\text { Can be used for prolonged periods of time }\end{array}$ & $\begin{array}{l}\text { Cost } \\
\text { Variable threshold of each device for tube } \\
\text { movement } \\
\text { May cause kinking or tube damage } \\
\text { Increase in risk of pressure ulcers due to higher } \\
\text { force applied to patient's face } \\
\text { Discomfort } \\
\text { May be associated with skin pressure breakdown } \\
\text { in prone position }\end{array}$ \\
\hline
\end{tabular}

ETT $=$ endotracheal tube

The authors ${ }^{17}$ created an extubation force by connecting the ETT to a digital force gauge and manually pulling in a perpendicular motion to the oral cavity until the entire cuff was removed from the trachea. The authors recorded the highest force that removed the tube as the extubation force. They found that the use of wide adhesive tape required the greatest force to dislodge the tube. They noted that although tape was superior in preventing extubation, their study did not address subject comfort, hygiene, or pressure on the skin. Shimizu et al ${ }^{17}$ recommended that tape be used to secure the tube, except in patients with facial hair, where a tube holder may be preferred.

Fisher et al ${ }^{18}$ recently evaluated 10 commercially available devices (manual resuscitation bag ETT holder with a blue strap and one with a white strap [Ambu, Glen Burnie, Maryland], Stabilock ETT holder [Dale Medical Products, Plainville, Massachusetts], AnchorFast [Hollister, Libertyville, Illinois], Thomas ETT holder, Marpac 320 with and without optional headgear (Marpac, Albuquerque, New Mexico), Quickstrap and Portex ETT holders [Smiths Medical, Dublin, Ohio], and Precision Medical cushioned ETT holder [Teleflex, Limerick, Pennsylvania]), along with 6 methods using either adhesive tape or cloth (twill) tape. They performed a series of complex experiments using a number of realistic models evaluating the ability of the tube-securing devices to prevent dislodgement and allow repositioning of the tube in the oral cavity. The tube dislodgement studies included a static tug test, rotational head studies, vertical head lift, and horizontal head turning. This group also uniquely measured the time to reposition the tube in the oral cavity from one side to the other. The authors concluded that no one device outperformed the others in all of the tests. They noted that many of the commercial securing devices appear to create significant pressure that could result in discomfort and the formation of pressure ulcers. They noted that using tape or cotton twill allowed for a custom-fit to the model's face and therefore reduced pressure issues seen with the commercial devices. However, the commercially available devices allowed quicker movement of the tube.

The data on commercial tube-securing devices compared to the traditional use of adhesive or cloth tape have failed to describe a clear advantage of either technique. Table 2 lists advantages and disadvantages of these 2 methods. Two recent reports describe unique adverse events (tongue necrosis, pilot balloon malfunction) related to commercial tube-securing devices. ${ }^{19,20}$ In our own experience, complications with these devices occur with some regularity. Figure 2 shows the kinking of a thermolabile ETT at the point of the tube attachment. The staff noted an increased airway resistance in this previously healthy young trauma patient. Airway flow demonstrated a fixed obstruction. This is recreated in Figure 2B, showing the point at which the tube was kinked. Figure 3 $(\mathrm{A}-\mathrm{C})$ shows facial pressure ulcers on the cheeks of 2 different patients after 1 week of prone positioning $(>18 \mathrm{~h} / \mathrm{d})$ that occurred at the edge of the tube fixation device. Table 2 compares homemade and commercially available systems for securing the ETT.

\section{Maintaining Airway Patency}

\section{Humidification}

Heating and humidifying cool dry medical gases are a standard of care during mechanical ventilation..$^{21,22}$ There is little argument regarding the requirement for heat and 


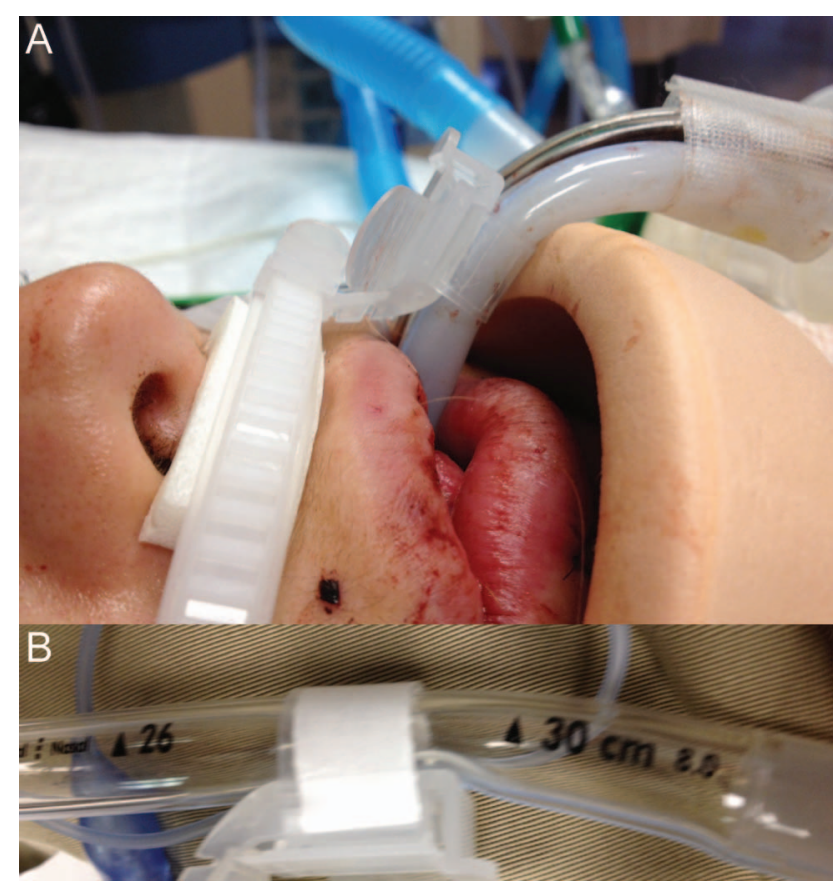

Fig. 2. A: Bend in the tube at the point of attachment creating increased airway resistance. B: Recreation of the problem shown in $A$.

humidity; however, the minimum or optimum requirements and ideal devices for humidification are frequently debated. The ability of any device, regardless of operation, to prevent drying of secretions depends on delivered gas temperature and relative humidity. ${ }^{23,24}$ Absolute humidity is the maximum amount of water that can be carried in a gas. Relative humidity represents the actual water vapor present as a percentage of the absolute humidity. Relative humidity is an important value, as any humidity deficit must be compensated for by the large airways of the tracheobronchial tree, a task for which it is ill suited. This is an important issue, as gas at low levels of relative humidity quickly absorbs moisture from the tracheobronchial mucosa and secretions in the airway. This can result in drying of secretions, mucus plugging, and airway obstruction.

There are no simple or agreed upon methods for monitoring the adequacy of humidification. A number of potential surrogates for evaluating humidification adequacy and comparing techniques have been suggested. These include secretion volume and consistency, incidence of ETT occlusion, changes in ETT effective diameter and/or resistance, suction frequency, and requirement for normal saline instillation. ${ }^{25-29}$ Measurements of secretion volume are subjective and inherently flawed. Secretion volume may change with the number of suction attempts, patient position, use of aerosolized medications, hyperinflation, and saline installation. Excessive humidification may cause an increase in secretion volume, whereas insufficient hu-

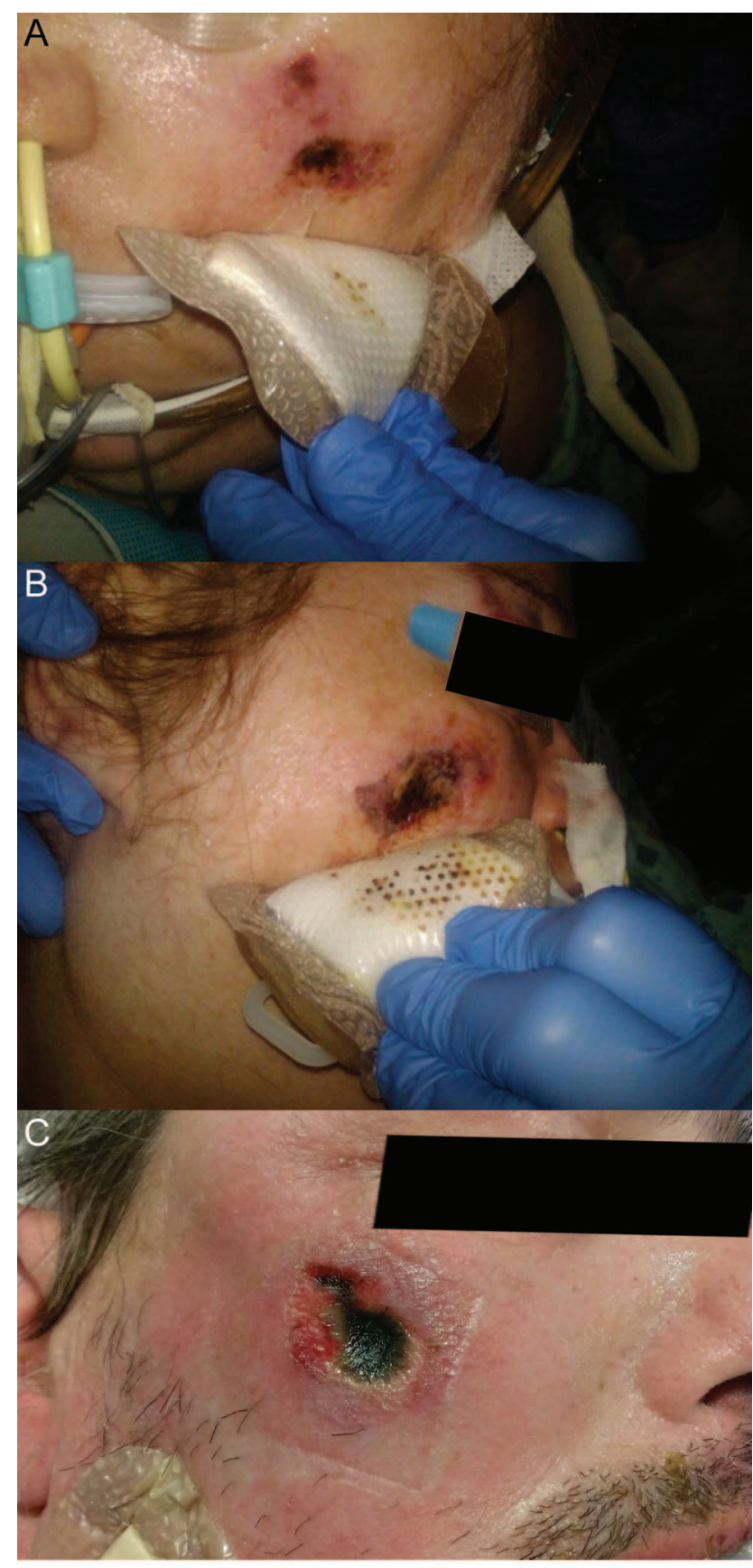

Fig. 3. A: Pressure ulcer on the left cheek of a patient after 1 week of prone positioning using a commercially available endotracheal tube (ETT) holder. B: Pressure ulcer on the right cheek of a patient after 1 week of prone positioning using a commercially available ETT holder. C: Pressure ulcer on the right cheek of a patient after 1 week of prone positioning using a commercially available ETT holder.

midification may result in a decrease in secretion volume as mucus becomes encrusted in the airways. ${ }^{25}$ In our experience, these surrogates are poorly reproducible and more likely reflect the individual practice of the clinician instead of the condition of the patient. Measures such as secretion 
volume and mucus volume are not reliable for comparisons of humidification adequacy.

\section{Heated Humidification Versus Heat-and-Moisture Ex- changers for Humidification and Secretion Manage-} ment. A comparison of the ability of heated humidifiers (HHs) and heat-and-moisture exchangers (HMEs) to optimize mucociliary function requires variables that are measurable and reproducible. A number of methods have been described to assess the adequacy of humidification. These include the incidence of ETT occlusion and changes in effective internal diameter of the ETT resulting from buildup of biofilm and encrusted secretions. Narrowing and occlusion of the ETT have been described with both $\mathrm{HHs}^{28-30}$ and HMEs. ${ }^{31-34}$

During use of an HH and a heated-wire circuit, ETT occlusion is associated with an increase in gas temperature from the humidifier chamber to the patient. As gas temperature rises, relative humidity falls. Gas entering the ETT at a humidity deficit absorbs moisture from secretions in the ETT and large airways. ${ }^{27}$ This problem can be avoided by maintaining a constant temperature from the chamber to airway and by using a connecting tube between the heated-wire circuit and airway, allowing for cooling and a relative humidity of $100 \%$. The problem of caregivers creating a large temperature difference between the chamber and airway to reduce condensate in the heated-wire circuit, which increased the risk of ETT occlusion, undoubtedly led to introduction of HHs with no such clinician-set control. ${ }^{35}$

Occlusion of the ETT during HME use occurs secondary to inadequate HME performance, changes in ambient conditions, leaks, and patient disease (eg, body temperature, minute ventilation, and fluid status). ${ }^{31-34,36,37} \mathrm{HME}$ construction and design play a large role, as hygroscopic devices clearly outperform hydrophobic devices. ${ }^{38-40}$ Even the most efficient HMEs result in a net loss of heat and moisture from the respiratory tract. As such, prolonged use is associated with greater incidence of ETT occlusion. There is also evidence that HMEs are less effective in patients with chronic lung disease, although this is not well understood. ${ }^{41}$

$\mathrm{Hess}^{42}$ evaluated studies comparing HMEs and HHs with or without a heated-wire circuit using a meta-analysis to determine the risk of ETT occlusion. These studies represent a cumulative total of over 1,000 subjects and demonstrate that the risk of ETT occlusion is nearly 4 times greater during HME use. These data argue against use of HMEs in patients with retained secretions and for limiting use to $<5 \mathrm{~d}$.

Another issue with HME use in patients with increased secretions is the possibility of occlusion of the HME device. This has not been specifically studied, but frequent soiling of the HME has been reported as a trigger for switching to an HH..$^{43}$ In our experience, an HME is more frequently occluded by blood or pulmonary edema fluid. However, in the presence of copious sputum volumes, an HME can become completely or nearly completely occluded.

A series of studies have evaluated the effects of humidification devices on in vivo and in vitro ETT resistance, internal diameter, and surface area. ${ }^{44-48}$ Villafane et al ${ }^{44}$ evaluated the effective internal diameter of ETTs by measuring flow and pressure at the proximal ETT and threading a catheter to measure pressure at the distal tip of the ETT. Three groups of subjects were studied: group 1 used an $\mathrm{HH}$, group 2 used a hygroscopic HME, and group 3 used a hydrophobic HME. The authors demonstrated that in vivo ETT resistance increased with duration of use in all study groups. However, tube resistance in the hydrophobic HME group was twice that seen in the hygroscopic HME group. ${ }^{44}$

Several groups have utilized acoustic reflectometry to evaluate reductions in effective internal diameter of ETTs. ${ }^{45-47}$ Boqué et al ${ }^{45}$ measured loss of effective internal diameter in a group of ventilated subjects who were using an HME for humidification. They found that within $48 \mathrm{~h}$, $>60 \%$ of tubes lost $>10 \%$ of the effective diameter. Shah and Kollef ${ }^{46}$ demonstrated similar losses of intraluminal surface area when comparing unused to used tubes. The most convincing evidence comes from Jaber et al, ${ }^{47}$ who used acoustic reflectometry to compare volume and resistance of ETTs in mechanically ventilated subjects over a 10-d period. Subjects used either an HH or HME. After $5 \mathrm{~d}$ of ventilator support, there was no difference in the changes in endotracheal resistance. However, at day 10, the HME group had a doubling of tube resistance: a $19 \pm 18 \%$ increase in resistance compared to only $8 \pm 12 \%$ for the HH group. The authors concluded that ETT resistance increases with duration of use and that use of an HME results in greater increases in ETT resistance. ${ }^{47}$

Wilson et $\mathrm{al}^{48}$ compared the pressure drop across new 7.0-8.5-mm ETTs to establish the resistance of each size. Pressure drop was measured at 30, 60, and $90 \mathrm{~L} / \mathrm{min}$. They then collected 71 ETTs following extubation of ventilated subjects. Pre-use measurements were repeated to determine the ex vivo changes created by use. Nearly three quarters of tubes had a pressure drop $>3$ SDs of unused tubes. This correlates to each size tube having a $0.5-\mathrm{mm}$ smaller effective diameter. They also found that in a small number of subjects $(<15 \%)$, the pressure drop was equivalent to an effective decrease in inner diameter of $1.5 \mathrm{~mm}$. Of note, the authors found that the pressure drop was not directly related to the duration of intubation: some tubes increased resistance in $2 \mathrm{~d}$ of use, whereas others had only small changes following longer durations of use. ${ }^{48}$

In a study with conflicting findings, Morán et al ${ }^{49} \mathrm{com}$ pared changes in ETT resistance in 44 subjects ( 22 in each 
group) using either an HME or HH. Subjects were matched for ETT diameter, days of mechanical ventilation, Simplified Acute Physiology Score II, and fluid balance. ETT resistance prior to use was compared to resistance measured immediately following extubation. Tube resistance increased following use from $6.8 \pm 1.1$ to $10.6 \pm$ $4.3 \mathrm{~cm} \mathrm{H}_{2} \mathrm{O} / \mathrm{L} / \mathrm{s}$ in the $\mathrm{HH}$ group and from $6.8 \pm 1.1$ to $10.2 \pm 3.8 \mathrm{~cm} \mathrm{H}_{2} \mathrm{O} / \mathrm{L} / \mathrm{s}$ in the HME group, an average increase of 53\% in resistive load. An important distinction in this study was selection of subjects. In most other reports, subjects were randomized to receive either an $\mathrm{HH}$ or HME. In this trial, the humidification device was selected for each subject based on clinical criteria. This means that subjects with thick secretions were more likely to receive heated humidification. This may explain why these findings contradict previous work.

These findings are clinically important, as several authors have described ETT resistance as a cause of weaning failure. ${ }^{50-52}$ Oto et $\mathrm{a}^{53}$ found that reduction in ETT resistance precludes the automatic tube compensation ventilator feature from completely overcoming ETT resistance. It also reinforces the fact that humidification devices should be chosen based on suspected duration of use, patient condition, and presence of thick secretions. ${ }^{43}$ In the mechanically ventilated patient with secretion management issues (thick and or copious amounts of sputum), the preferred method of humidification is heated humidification. Additionally, the presence of pulmonary edema or hemoptysis should preclude HME use to avoid obstruction of the HME. When mechanical ventilation is expected to last beyond $96 \mathrm{~h}$, an HH should likely be used from the outset.

\section{Maintaining the Endotracheal Tube Lumen}

Humidification maintains mucociliary function and prevents drying of secretions such that they can be removed. In the intubated patient, the ETT cuff abruptly acts as an obstruction to the mucociliary escalator. When secretions are delivered to the tip of the ETT, suctioning is typically required. Methods include open- and closed-circuit suctioning and minimally invasive or shallow suctioning. Another contentious issue in suctioning remains the instillation of normal saline to either loosen secretions or stimulate a cough to aid in secretion removal. Suction frequency and suctioning based on clinical findings are also issues that require definition.

Suctioning. Removal of tracheobronchial and upper airway secretions to maintain airway patency is also a standard of care. ${ }^{54,55}$ Suction catheters vary widely in design but have the same general characteristics. Most adult suction catheters are $48-56 \mathrm{~cm}$ in length, allowing the catheter to travel into the main bronchus. The distal tip of the catheter typically includes several openings for secretion removal, and the proximal portion contains a thumb port that is occluded by the practitioner to activate the suction. The distal tip of the catheter is blunt to avoid trauma to the mucosa and possible perforation of the trachea. The side holes in the distal tip of the catheter also serve to limit local tissue damage by preventing excessive negative pressure applied to the mucosa. Suction catheters should be transparent to allow visual inspection of secretions and rigid enough to pass through the ETT, yet flexible enough to traverse airway structures without damaging mucosa.

Few comparative evaluations of suction catheter designs have been accomplished. ${ }^{56,57}$ Shah et al ${ }^{57}$ compared six 14 French suction catheters in a bench study evaluating the characteristics (side hole placement) that facilitated removal of a mucus simulant. The viscosity of the simulated mucus was altered to represent thin and thick secretions. These authors found that the major factors affecting secretion removal were the position and size of the catheter side holes. Offset side holes were associated with improved removal of mucus. These findings provide important guidance for future catheter designs.

Open Versus Closed Suctioning. For many years, the standard of care for suctioning the artificial airway was a single-use, disposable, open-circuit suction catheter. The patient was disconnected from the ventilator, hyperventilated, and hyperoxygenated with a self-inflating manual resuscitator, and the catheter was passed into the ETT for removal of secretions. The manual resuscitator was also used to simulate a cough by stacking breaths or giving a large volume. This procedure was also known to result in both hemodynamic instability and, during the suction procedure, hypoxemia.

Over the last decade, closed-circuit suction catheters have become popular for a host of reasons. These include prevention of adverse events associated with disconnecting the patient from the ventilator and loss of PEEP, reduced costs, and reduced exposure of caregivers to patient secretions. Comparisons of closed- and open-circuit suction techniques suggest that there is little difference in the ability of each device to remove secretions. ${ }^{58,59}$ Because the patient does not need to be disconnected from the ventilator when closed-circuit suctioning is used, PEEP is maintained, and hypoxemia appears to be lessened. There is also some suggestion that closed-circuit suctioning reduces caregiver and environmental contamination, although this evidence is weak. Comparison of open- and closedsuction systems suggests that the incidence of ventilatorassociated pneumonia (VAP) is unchanged. ${ }^{60-78}$ Popular opinion suggests that by preventing disconnection of the circuit during suctioning, the risk of VAP is reduced, listing this as an important feature of closed-circuit suctioning. Although this is an attractive hypothesis, it has not been specifically studied. When closed-circuit suctioning 
was first introduced, it was the opinion of this author (RD Branson) that the quantity of secretions removed was lower than with open-circuit suctioning. I also believed that eliminating the manual resuscitator not only prevented the clinician from feeling the compliance, but reduced the ability to create a cough to propel mucus cephalad. One of the most obvious differences with closed-circuit suctioning is the muted sound since the airway is closed. However, this did not explain why fewer secretions seemed to be removed. One advantage with respect to adverse events with closed-circuit suctioning is that PEEP is preserved. However, this also means that, during aspiration, the ventilator is being triggered and adding flow into the airway, pushing secretions away from the catheter, so closed-circuit suctioning, with all the listed advantages, may be an inferior secretion removal device.

This hypothesis was evaluated by Lasocki et al, ${ }^{78}$ who compared the effects of open- and closed-circuit suctioning in subjects with respiratory failure. The major finding of their study was that closed suctioning prevented suction-related hypoxemia; however, secretion removal was reduced. They proposed that, during open-circuit suctioning, the disconnection from the ventilator and loss of PEEP simulate a cough, propelling mucus upward. They also postulated that removal of the ventilator increases the pressure differential for enhanced suctioning and that, during closed-circuit suctioning, the ventilator gas delivery maintaining PEEP forces secretions away from the suction catheter. They noted that by increasing the suction pressure to $-400 \mathrm{~mm} \mathrm{Hg}$, secretion volumes were equivalent to open suctioning. They did not observe that the greater negative pressure was associated with increased incidence of hypoxemia. The authors did suggest, however, use of a recruitment maneuver post-suctioning to restore alveolar volume. ${ }^{78}$ Despite these findings, closed-circuit suctioning appears to have more advantages than disadvantages. In patients with retained secretions, increasing vacuum pressure may be required for improved secretion removal, but gas exchange and ventilator performance should be monitored closely.

In a recent study, Adi et al ${ }^{79}$ evaluated a closed-circuit catheter with an integral closed-circuit cleaning system enabling it to eliminate the buildup of secretions in the lumen of the ETT. However, this was accomplished using ETTs following extubation. The usefulness of this device for managing the airway in intubated subjects has not been evaluated. Corley et al ${ }^{80}$ evaluated the impact of cleaning closed-circuit suction catheters on lung volumes in a series of mechanically ventilated subjects. They compared devices that incorporated a one-way valve between the catheter and the airway and one that did not. Using electrical impedance tomography, they compared subject lung volumes during cleaning of the suction catheters with saline. The presence of the one-way valve prevented loss of lung volumes during catheter cleaning. These findings suggest that improvements to suction devices are still needed.

Bronchial Suctioning. During routine endotracheal suctioning, the suction catheter most likely enters the right main bronchus if advanced the full length. This results from the more acute angle of the left main bronchus at the carina compared with the right main bronchus. As such, the left bronchus is less likely to be suctioned. Attempts at suctioning the left main bronchus have been described and range from simple maneuvers to use of specially designed catheters. ${ }^{81-84} \mathrm{~A}$ simple method for suctioning the left main bronchus is turning the patient's head to the right in an attempt to increase the likelihood of passage of the catheter into the left main bronchus. The same effect may be gained by placing the patient in the left lateral position and using gravity to further the catheter's passage.

Specialized catheters using a curved tip have been shown to enter the left main bronchus in up to $90 \%$ of cases. ${ }^{84}$ The success of bronchial suctioning can be affected by tube position, patient body and head position, and type of tube (ETT vs tracheostomy tube). The necessity of selective suctioning of the left bronchus has not been described. Frequent changes in patient body position facilitate movement of secretions to the carina, where they can be suctioned. In patients with infectious processes confined to the left lung, selective endobronchial suctioning may prove useful.

Deep Versus Shallow Suctioning. The length of the suction catheter in neonates is often measured to prevent traversing the tip of the ETT. This is done to prevent trauma to the tracheobronchial mucosa, bleeding, and agitation of the patient. Shallow or minimally invasive suctioning involves passing the catheter to the end of the ETT, but no further. Suctioning past the ETT tip is termed deep suctioning. This issue has rarely been considered in adults.

A previous meta-analysis found that the supporting literature is poor and that no definitive conclusions could be made in the deep versus shallow suction debate. ${ }^{84} \mathrm{Ahn}$ and Hwang ${ }^{85}$ examined secretions from neonates following deep and shallow suctioning and found evidence of detached ciliated airway cells only after deep suctioning. There was no increase in secretions removed during deep suctioning compared to shallow suctioning. They concluded that deep suctioning has no advantage, causes unnecessary trauma, and should be avoided.

Spence et $\mathrm{al}^{84}$ updated their Cochrane review of deep and shallow suctioning in neonates. They identified 2 additional studies, only one of which met criteria for inclusion. This additional crossover trial of 27 subjects demonstrated no differences in changes in heart rate or oxygen saturation during or after the suction procedure between the 2 techniques. 
In adults, Van de Leur et al ${ }^{86}$ demonstrated that minimally invasive suctioning resulted in fewer recollections of suctioning by ventilated subjects. However, this was not associated with less discomfort during the suction procedure. In a large study of adult subjects, they also demonstrated that minimally invasive suctioning resulted in fewer hemodynamic and gas exchange side effects while having no effect on duration of ventilation and other outcomes. ${ }^{87}$ In this study, the traditional suction catheter was $49 \mathrm{~cm}$ in length versus $29 \mathrm{~cm}$ for the minimally invasive catheter.

This issue essentially pits deep suctioning to remove the maximum amount of secretions against just keeping the ETT clear of secretions. The limited evidence seems to suggest that minimally invasive suctioning is as effective at secretion removal but has fewer side effects. Based on these data, using the first-do-no-harm principle, minimally invasive suctioning may be preferred.

Use of Saline Instillation. During suctioning, some practitioners instill 5-10 $\mathrm{mL}$ of normal saline in an attempt to thin tracheobronchial secretions. This practice remains a point of contention, and studies have failed to show any advantages. Our own studies regarding humidification reveal that the only predictor of saline instillation is practitioner preference. ${ }^{43}$ Saline instillation frequently causes the patient to cough violently, which may aid in secretion removal. From a conceptual standpoint, the use of saline to stimulate a cough makes sense, but the current literature does not support this practice. From a mucus rheology perspective, the properties of mucus are unlikely to change with the addition of saline unless some physical means of mixing is accomplished. However, severe coughing episodes, hypoxemia, hypertension, and bronchospasm occasionally may result from saline instillation.

There is also some concern that the use of saline may dislodge bacteria-laden biofilm from the ETT, resulting in infectious consequences. A host of studies demonstrate that saline instillation fails to produce any of the intended effects while potentially resulting in higher infection rates. ${ }^{88-105}$ Based on this evidence, the use of saline to thin secretions is, at best, unsupported and, at worst, dangerous.

When to Suction. Guidelines suggest that the use of routine suctioning should be avoided. ${ }^{55}$ Assessment of the patient, including auscultation and visual inspection, should be used to determine the need for endotracheal suctioning. Jubran and Tobin ${ }^{106}$ were among the first to describe the use of ventilator graphics to detect the need for endotracheal suctioning. Guglielminotti et $\mathrm{al}^{107}$ and Zamanian and Marini ${ }^{108}$ also described alterations in the pressure and flow curves that might suggest the need for suctioning. The most common finding is a sawtooth pattern in the expiratory flow signal caused by secretions in the large airways. This finding is also seen with condensate in the
Table 3. Components of the AARC Clinical Practice Guidelines Implemented to Reduce Suction-Related Complications

Suction only when clinically indicated

Avoid disconnection and loss of PEEP

Shallow suction to the tip of the ETT

Avoid saline installation

Catheter diameter $<50 \%$ of the ETT internal diameter

Duration of suctioning $<15 \mathrm{~s}$

Suction pressure $<180 \mathrm{~mm} \mathrm{Hg}$

Only closed-circuit suctioning to be used in ARDS

From Reference 110

AARC $=$ American Association for Respiratory Care

$\mathrm{ETT}=$ endotracheal tube

expiratory limb of the ventilator circuit, so visual inspection of the circuit should be included in the evaluation.

Visaria and Westenskow ${ }^{109}$ demonstrated the ability to detect ETT occlusion using an automated evaluation of pressure and flow signals. They were able to distinguish airway obstruction from bronchospasm and changes in chest wall compliance. Similar systems might be developed to determine when suctioning is required.

Endotracheal suctioning is associated with a litany of complications and should be undertaken only when necessary, keeping the potential complications in mind. Minimizing these complications by minimally invasive suctioning and suctioning only when necessary based on reliable detection methods may both be routine practice in the future.

A recent paper highlighted these factors, implementing the American Association for Respiratory Care (AARC) clinical practice guidelines to ascertain the impact. ${ }^{110}$ Over a 3-month period, the authors studied 79 mechanically ventilated subjects and identified adverse effects in 4,506 suction procedures. They implemented the AARC clinical practice guidelines and, 1 y later, studied 68 subjects undergoing 4,994 suction procedures. The main components implemented are shown in Table 3. In the first period, adverse effects were common. The most frequent complication was oxygen desaturation ( $47 \%$ of subjects and $6.5 \%$ of procedures), bloody secretions (32\% of subjects and $4 \%$ of procedures), blood pressure change (24\% of subjects and $1.6 \%$ of procedures), and heart rate change (10\% of subjects and $1 \%$ of procedures). After implementation of the guidelines, all complications were reduced. The incidence of all complications decreased from 59 to $42 \%$ of subjects and from 12 to $5 \%$ of all procedures. The incidence of oxygen desaturation was associated with PEEP $>5 \mathrm{~cm} \mathrm{H}_{2} \mathrm{O}$ and $>6$ suctionings/d. Receiving $>6$ suctionings/d was also a risk factor for bloody secretions. The authors concluded, "Endotracheal suctioning frequently induces adverse effects. Technique, suctioning frequency, and higher PEEP are risk factors for complications. Their 
incidence can be reduced by the implementation of suctioning guidelines." 110 This study is an excellent example of putting good ideas into practice and monitoring the outcome.

\section{Novel Methods for Secretion Removal From the Endotracheal Tube}

Mucus Slurper. Intermittent closed-circuit suctioning is the most commonly used method to suction mechanically ventilated patients. Kolobow et al ${ }^{111}$ have described a system that provides automated intermittent suctioning of the ETT lumen. They have termed this system the Mucus Slurper. The ETT is modified to include a portion extending beyond the cuff with 8 holes $1.3 \mathrm{~mm}$ in diameter. A suction lumen extends below the cuff to apply suction to these 8 holes. The system draws $135 \mathrm{~mL}$ over $0.3 \mathrm{~s}$. In their initial evaluation in an animal model, the suction system did not affect ventilator performance. There is some concern for autotriggering, but most ventilators have a lockout time following completion of the inspiratory time $\sim 0.3 \mathrm{~s}$ in duration.

This early evidence demonstrated that in an animal model without pulmonary disease, the endotracheal lumen remains clean. Presumably as the secretions approach the ETT, they are removed through the 8 narrow holes. A second animal trial evaluated this system for $72 \mathrm{~h}$ and compared every 2-min activation with the Mucus Slurper to every 6-h manual suctioning. ${ }^{112}$ There were no differences in airway colonization between groups. However, ETTs demonstrated a reduction in secretion accumulation in the Mucus Slurper group. The authors also measured protein content in the expiratory condensate as a marker of secretion movement up the ETT. The protein concentrations were lower in the Mucus Slurper group. How this system will perform in a patient with copious tenacious secretions remains to be seen.

Mucus Shaver. Kolobow et al ${ }^{113}$ also described a system for removal of secretions within the ETT known as the Mucus Shaver. This is a manually operated system for scraping the inside of the ETT to remove secretions. The Mucus Shaver is placed inside the ETT much like a stylet. The balloon is inflated, and the shaving heads are forced against the inner lumen of the tube. The Mucus Shaver is then withdrawn over 3-5 s to remove any dried secretions. The intention is to return the resistance characteristics of the ETT to pre-use values. In an animal model with normal lungs, the Mucus Shaver maintained a clean internal lumen and reduced biofilm accumulation. Berra et al ${ }^{114}$ recently tested the Mucus Shaver in a group of 24 subjects requiring mechanical ventilation for at least $72 \mathrm{~h}$. Subjects were randomized within $2 \mathrm{~h}$ of intubation to receive standard airway suctioning alone or with the addition of the
Mucus Shaver until extubation. They found that, at extubation, only one ETT from the Mucus Shaver group was colonized versus 10 colonized ETTs in the control group. Scanning electron microscopy showed very little secretions in the ETTs in the Mucus Shaver group, whereas thick bacterial deposits were present on all tubes from the control group. They concluded that the Mucus Shaver is a safe, feasible, and efficient device for cleaning the internal lumen of ETTs. The Mucus Shaver also prevented ETT colonization. This preliminary evidence is intriguing but does not demonstrate a decrease in the incidence of infection or VAP. The accumulation of biofilm on the ETT is thought to play a role in the pathogenesis of VAP, so the removal of that material appears to have some clinical importance. However, the authors did not discuss issues related to cost in their trial. The nursing staff was satisfied with the device, but larger trials with clinically important end points are needed.

\section{Biofilm Prevention}

A number of ideas have emerged to reduce biofilm accumulation in the ETT using impregnated materials. A silver-coated or silver-impregnated tube is a commercially available product intended to reduce bacterial colonization and maintain a patent lumen. Silver has long been appreciated for its bacteriostatic properties. ${ }^{115-117}$ Some readers will remember a time when all tracheostomy tubes were silver or silver-plated over stainless steel. Silver-coated or silver-impregnated urinary catheters and central venous catheters have been used in an effort to reduce infection for over a decade. ${ }^{118}$ Silver prevents biofilm formation and reduces bacterial burden and inflammation. Olson et al ${ }^{119}$ performed an experimental study in 11 ventilated dogs to evaluate the biofilm prevention properties of a silver-coated ETT. They reported that silver-coated tubes reduced biofilm formation, with a significant lumen-narrowing difference between tubes. Five of 6 non-coated tubes $(83 \%)$ and none of 5 coated tubes $(0 \%)$ had a narrowing of $>50 \%$. Coated tubes reduced the bacterial burden and also delayed the duration of luminal side colonization from 1.8 to $3.2 \mathrm{~d} .{ }^{119}$

A prospective randomized phase- 2 pilot study testing silver-coated ETTs in ICU subjects was designed to determine whether silver-coated ETTs reduce the incidence and/or delay the time of onset of colonization compared to non-coated ETTs. ${ }^{120}$ The results demonstrated a significant reduction in microbiologic burden associated with silver-coated ETT.

Raad et al ${ }^{121}$ evaluated the prevention of biofilm colonization in ETTs coated with silver and tubes coated with gardine or gendine. Gardine is a combination of 2 antiseptic agents, Brilliant Green (an antiseptic dye) and chlorhexidine. Gendine is a combination of gentian violet and chlorhexidine. ${ }^{121}$ In an in vitro study, they found that both 
gardine- and gendine-coated ETTs were superior to silvercoated ETTs in preventing biofilm formation. These treatments are also considerably cheaper than silver coating. Similar studies have been done previously using silver- and chlorhexidine-coated or antimicrobial-coated tubes. ${ }^{122,123}$ Berra et al ${ }^{124}$ combined the Mucus Shaver with antimicrobial-coated tubes to maximize the impact of each. Interestingly, photodynamic therapy has also been advocated as a potential method to reduce biofilm formation. ${ }^{125}$

The high level of bacterial concentration in the inner surface of a standard ETT can play a role in the development of late-onset VAP when biofilm fragmentation occurs. This fragmentation is potentiated during saline installation and airway suctioning.

\section{Monitoring Endotracheal Tube Position and Patency}

Under normal conditions, monitoring ETT patency and position is accomplished using routine assessments, including auscultation, monitoring position of the ETT at the lips or teeth, and routine chest radiographs. The tube is secured as has been described earlier to prevent dislodgement or distal migration. In the interim, problems with tube position typically manifest from ventilator alarms (low and high pressure, loss of PEEP, low minute volume) or obvious patient distress.

A device using acoustic reflectometry has been introduced to continuously monitor both tube position and lumen patency (AirWave, SonarMed, Carmel, Indiana). Using a specialized ETT adapter to replace the standard adapter, the device uses sound waves to monitor the internal lumen of the tube and the position relative to the carina. A visual display of tube position and percentage of lumen obstruction is included. This device is based on work described previously. ${ }^{45}$

Nacheli et al ${ }^{126}$ completed a pilot study to evaluate the AirWave device in detecting ETT migration in a small group of adult subjects. They compared acoustic monitoring of the ETT to measurement of the tube at the teeth and chest radiography. The device detected obstruction that was easily removed by suctioning in a number of subjects in real time. The device was no better than the usual standard of care in detecting tube migration. Interestingly, of the 42 subjects enrolled, 22 were withdrawn. Of these, 9 had an AirWave sensor malfunction, and 5 had the adapter removed. This suggests that there are educational and technical issues associated with application of the device. As is often the case, the authors did not discuss the financial implications of using the device. There may be some utility in use of this device for detecting tube position, which has been shown to be difficult to ascertain by tube marking at the teeth and radiography. ${ }^{127}$ However, the costs and any benefit remain to be determined.

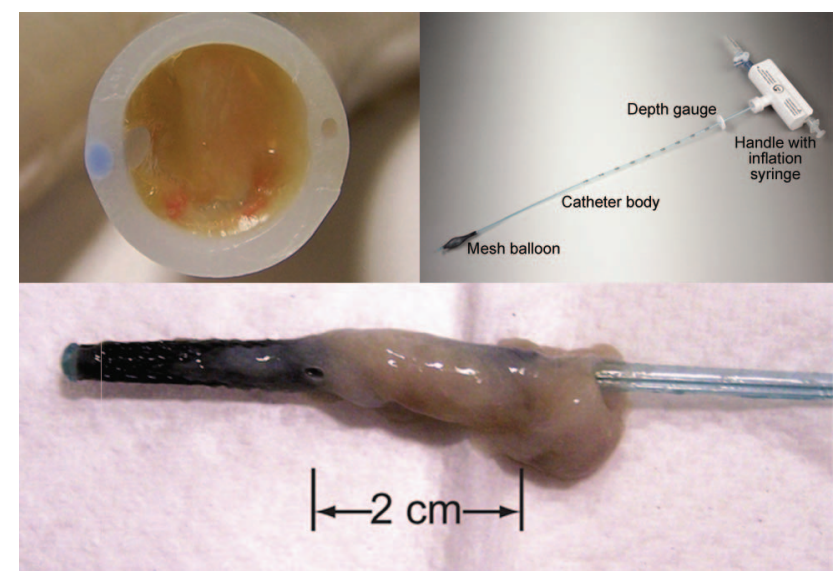

Fig. 4. The results of cleaning the endotracheal tube with the CAM Rescue Cath. From Reference 128.

\section{Rescuing the Endotracheal Tube}

Partial or complete obstruction of the ETT can be a catastrophic event in the ICU. Much of this paper has discussed avoidance of this issue. Tube patency is commonly evaluated by passing a suction catheter and judging the ease of movement through the tube. The Mucus Shaver is one device that can be used to rescue the ETT by removing the obstruction.

A couple of new devices have been introduced to address the issue of rescuing the ETT in the presence of obstruction. These include the endOclear (Endoclear, San Ramon, California) and the CAM Rescue Cath (Omneotech, Tavernier, Florida); both are designed to remove mucus secretions from the airway. Stone and Bricknell ${ }^{128}$ and Mietto et al ${ }^{129}$ have both recently described their experience with these devices in a case series with mucus obstructions of the ETT. The devices are similar in principle to the Mucus Shaver, with an inflatable balloon at the distal tip that is inflated prior to pulling the catheter out of the ETT. The results obtained by Stone and Bricknell with the CAM Rescue Cath are shown in Figure 4. This system offers an alternative to bronchoscopy and would be quicker and less expensive to implement in an emergency situation. The use of such a device routinely to prevent tube narrowing cannot currently be supported, but it is the hypothesis of an ongoing clinical trial. ${ }^{130}$

\section{Cuff Pressure Management}

Accumulation of secretions above the ETT cuff and microaspiration around the cuff are clearly implicated in the pathogenesis of VAP. Maintenance of cuff pressure and volume to prevent aspiration is in important task of the respiratory therapist. However, pressures to prevent microaspiration have to be balanced against excessive 


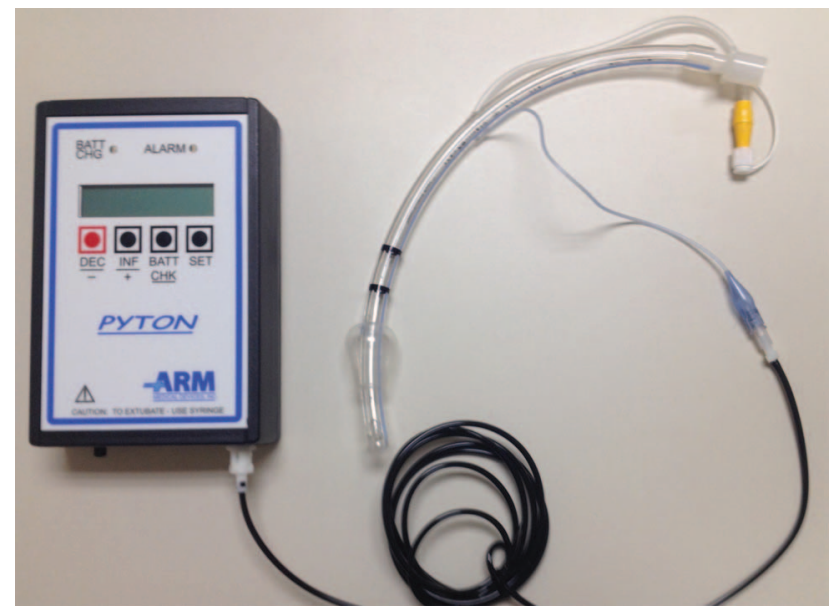

Fig. 5. A commercially available automated cuff pressure controller.

pressures damaging the tracheal mucosa. A pressure $<30 \mathrm{~cm} \mathrm{H}_{2} \mathrm{O}$ is commonly selected to prevent reduction to mucosal blood flow and the attendant consequences. ${ }^{131}$

High-volume low-pressure cuffs were developed to prevent mucosal damage while still preventing fluid leakage. However, microchannels in these high-volume cuffs can allow migration of fluid into the lower respiratory tract. Monitoring cuff pressure with a device to determine pressure and modulate the volume is a common practice. However, these measurements are made infrequently and typically under controlled conditions. Sole et al ${ }^{132}$ conducted a trial using continuous cuff pressure monitoring with constant cuff pressures of $20 \mathrm{~cm} \mathrm{H}_{2} \mathrm{O}$ to determine the impact on VAP incidence. They failed to find any differences in VAP rate. Rello et $\mathrm{al}^{133}$ found that cuff pressures $<20 \mathrm{~cm} \mathrm{H}_{2} \mathrm{O}$ during the first $8 \mathrm{~d}$ of intubation were an independent risk factor for the development of VAP (relative risk 4.23, 95\% CI 1.12-15.92). This finding led investigators to consider methods to continuously monitor cuff pressures and to evaluate the role of automatic cuff pressure control using closed-loop control. ${ }^{134}$

A number of devices have been developed to continuously maintain cuff pressure using an electrically controlled pump, gas supply, or integral to the ventilator. ${ }^{135}$ An example of a stand-alone device is shown in Figure 5.

A number of trials have evaluated the use of both pneumatic and electronic cuff pressure controllers. Kunitz et al ${ }^{136}$ compared cuff pressure managed intra-operatively with a cuff pressure controller versus manual control. They randomized 80 subjects, 40 in each group. The controller maintained cuff pressure at $25 \pm 2 \mathrm{~cm} \mathrm{H}_{2} \mathrm{O}$, whereas cuff pressures $>40 \mathrm{~cm} \mathrm{H}_{2} \mathrm{O}$ were frequently observed in the manual control group. These findings likely represent the diffusion of nitrous oxide into the cuff. The study outcome variables were the presence of hoarseness, coughing, and pain while swallowing. Subjects using automated cuff pressure control had reduced frequency and severity of hoarse- ness and coughing but no change in pain while swallowing.

Farré et al ${ }^{137}$ studied cuff pressures in a bench study and in 8 mechanically ventilated subjects managed for $24 \mathrm{~h}$. Cuff pressures were maintained at $25 \mathrm{~cm} \mathrm{H}_{2} \mathrm{O}$ throughout the trial. In the bench study, the cuff pressure controller eliminated cuff pressure fluctuations associated with positive-pressure ventilation. This was a proof-of-concept study, and no other end points were evaluated. ${ }^{137}$ Nseir et al ${ }^{138}$ evaluated tracheal wall damage in an animal model when cuff pressure was managed manually or with a cuff pressure controller. The controller maintained cuff pressure in the desired range more often than manual control. However, there were no differences in the scores for airway damage. ${ }^{138}$

In human studies, the findings are similar. Farré et al ${ }^{137}$ used a prospective randomized crossover pilot study to evaluate a pneumatic cuff pressure controller. They studied 8 subjects over two 24-h periods in random order. During use of the cuff pressure controller, pressures remained between 15 and $30 \mathrm{~cm} \mathrm{H}_{2} \mathrm{O} 96 \%$ of the time during the observation period versus only $56 \%$ of the time during manual control. Additionally, cuff pressures $<15 \mathrm{~cm} \mathrm{H}_{2} \mathrm{O}$ occurred 3 times more often during manual control (5 vs $15 \%$ ). ${ }^{137}$ Valencia et al ${ }^{139}$ evaluated the impact of automatic cuff pressure control in 142 mechanically ventilated subjects without pneumonia on admission. Manual management of the cuff was done 3 times daily using a pressure manometer. Low cuff pressure occurred in $<1 \%$ of subjects using automatic control versus $45 \%$ of subjects in the manual control group. However, despite this finding, the incidence of VAP in each group was equivalent (15\%). ${ }^{139}$ Nseir et al ${ }^{140}$ compared automated versus manual cuff pressure management in 122 subjects intubated with polyvinyl chloride cuffs. They also found very few low-pressure conditions in the automated control group $(0.1 \%)$ compared to the manual management group $(19 \%)$. They found a lower incidence of the presence of pepsin in tracheal aspirates (suggesting gastric aspiration), a lower bacterial concentration, and a decreased incidence of VAP ( 10 vs $26 \%, P<.032$, odds ratio $0.30,95 \%$ CI 0.11 $0.84)$ in the automated control group. They did not find any difference in ICU days or ventilator days, and no difference was seen in mucosal ischemia scores. ${ }^{140} \mathrm{~A}$ recent study evaluated a pneumatic cuff pressure controller versus manual cuff pressure management in a group of subjects intubated with polyurethane cuffs. ${ }^{141}$ The authors found that the mean cuff pressure was $26 \mathrm{~cm} \mathrm{H}_{2} \mathrm{O}$ (interquartile range 24-28) versus $22 \mathrm{~cm} \mathrm{H}_{2} \mathrm{O}$ (interquartile range 20-28) during continuous control versus manual control. Underinflation (31 vs 68\%) and overinflation (53 vs $100 \%$ ) were less common with continuous control compared with manual management. However, there were no 


\section{Management of the Artificial Airway}

significant differences in microaspiration of gastric contents between groups. ${ }^{141}$

One explanation as to why clinical outcomes have failed to demonstrate consistent advantages may be related to the method of control. Weiss et al ${ }^{142}$ demonstrated that rapid pressure correction with automated control interferes with the self-sealing mechanisms of high-volume low-pressure polyvinyl chloride-cuffed tracheal tubes. This finding has also been reported by Brisson et al ${ }^{143}$ The use of automated cuff pressure control simplifies the job of the clinician, is more consistent, and may lead to improved airway care. The evidence is mounting but is not compelling. Costs are also not discussed in these studies.

\section{Summary}

Management of the artificial airway is an important skill of the respiratory therapist. Technology can both aid and hinder this practice. It is the responsibility of the clinician to understand and apply new technology when it enhances care and is cost-effective.

\section{REFERENCES}

1. Branson RD. Secretion management in the mechanically ventilated patient. Respir Care 2007;52(10):1328-1342; discussion 1342-1347.

2. ECC Committee, Subcommittees and Task Forces of the American Heart Association. 2005 American Heart Association guidelines for cardiopulmonary resuscitation and emergency cardiovascular care. Circulation 2005;112(24 Suppl):IV1-IV203.

3. da Silva PS, Fonseca MC. Unplanned endotracheal extubations in the intensive care unit. Anesth Analg 2012;114(5):1003-1014.

4. Zaratkiewicz S, Teegardin C, Whitney JD. Retrospective review of the reduction of oral pressure ulcers in mechanically ventilated patients: a change in practice. Crit Care Nurs Q 2012;35(3):247254.

5. The Joint Commission. 2013 National Patient Safety Goals. http:// www.jointcommission.org/standards_information/npsgs.aspx. Accessed December 28, 2013.

6. Levy H, Griego L. A comparative study of oral endotracheal tube securing methods. Chest 1993;104(5):1537-1540.

7. Kaplow R, Bookbinder M. A comparison of four endotracheal tube holders. Heart Lung 1994;23(1):59-66.

8. Barnason S, Graham J, Wild MC, Jensen LB, Rasmussen D, Schulz $\mathrm{P}$, et al. Comparison of two endotracheal tube securement techniques on unplanned extubation, oral mucosa, and facial skin integrity. Heart Lung 1998;27(6):409-417.

9. Gardner A, Hughes D, Cook R, Henson R, Osborne S, Gardner G. Best practice in stabilisation of oral endotracheal tubes: a systematic review. Aust Crit Care 2005;18(4):158:160-165.

10. Lovett PB, Flaxman A, Stürmann KM, Bijur P. The insecure airway: a comparison of knots and commercial devices for securing endotracheal tubes. BMC Emerg Med 2006;6:7.

11. Murdoch E, Holdgate A. A comparison of tape-tying versus a tubeholding device for securing endotracheal tubes in adults. Anaesth Intensive Care 2007;35(5):730-735.

12. Carlson J, Mayrose J, Krause R, Jehle D. Extubation force: tape versus endotracheal tube holders. Ann Emerg Med 2007;50(6):686691.
13. Owen R, Castle N, Hann H, Reeves D, Naidoo R, Naidoo S. Extubation force: a comparison of adhesive tape, non-adhesive tape and a commercial endotracheal tube holder. Resuscitation 2009; 80(11):1296-1300.

14. Carlson JN, Mayrose J, Wang HE. How much force is required to dislodge an alternate airway? Prehosp Emerg Care 2010;14(1):3135 .

15. Farbod F, Tuli P, Robertson BF, Jackson IT. Endotracheal tube fixation methods for optimal stability: a comparison of adhesive tape, suture, and tape-suture fixation. J Craniofac Surg $2010 \mathrm{Jul}$; 21(4):1250-1251.

16. Kupas DF, Kauffman KF, Wang HE. Effect of airway-securing method on prehospital endotracheal tube dislodgment. Prehosp Emerg Care 2010;14(1):26-30.

17. Shimizu T, Mizutani T, Yamashita S, Hagiya K, Tanaka M. Endotracheal tube extubation force: adhesive tape versus endotracheal tube holder. Respir Care 2011;56(11):1825-1829.

18. Fisher DF, Chenelle CT, Marchese A, Kratohvil J, Kacmarek RM. Comparison of commercial and non-commercial endotracheal tube securing devices. Respir Care 2013 [Epub ahead of print] doi: 10.4187/respcare.02951

19. Kuhn MA, Zeitler DM, Myssiorek DJ. Tongue necrosis: a rare complication of oral intubation. Laryngoscope 2010;120(Suppl S4): S159.

20. Adams JR, Hoffman J, Lavelle J, Mireles-Cabodevila E. Pilot balloon malfunction caused by endotracheal tube bite blockers. Respir Care 2014;59(2):e22-e24.

21. American Association for Respiratory Care, Restrepo RD, Walsh BK. Humidification during invasive and noninvasive mechanical ventilation: 2012. Respir Care 2012;57(5):782-788.

22. American Association for Respiratory Care. Consensus statement on the essentials of mechanical ventilators-1992. Respir Care 1992; 37(9):1000-1008.

23. Williams R, Rankin N, Smith T, Galler D, Seakins P. Relationship between the humidity and temperature of inspired gas and the function of the airway mucosa. Crit Care Med 1996;24(11):1920-1929.

24. Rankin N. What is optimum humidity? Respir Care Clin N Am 1998;4(2):321-328.

25. Sottiaux TM. Consequences of under and over humidification. Respir Care Clin N Am 2006;12(2):233-252.

26. Branson RD. The effects of inadequate humidity. Respir Care Clin N Am 1998;4(2):199-214.

27. Suzukawa M, Usuda Y, Numata K. The effects of sputum characteristics of combining an unheated humidifier with a heat-moisture exchanging filter. Respir Care 1989;34(11):976-984.

28. Miyao H, Hirokawa T, Miyasaka K, Kawazoe T. Relative humidity, not absolute humidity, is of great importance when using a humidifier with a heating wire. Crit Care Med 1992;20(5):674-679.

29. Nishida T, Nishimura M, Fujino Y, Mashimo T. Performance of heated humidifiers with a heated wire according to ventilatory settings. J Aerosol Med 2001;14(1):43-51.

30. Gilmour IJ, Boyle MJ, Rozenberg A, Palahniuk RJ. The effect of heated wire circuits on humidification of inspired gases. Anesth Analg 1994;79(1):160-164.

31. Cohen IL, Weinberg PF, Fein IA, Rowinski GS. Endotracheal tube occlusion associated with the use of heat moisture exchangers in the intensive care unit. Crit Care Med 1988;16(3):277-279.

32. Martin C, Perrin G, Gevaudan MJ, Saux P, Gouin F. Heat and moisture exchangers and vaporizing humidifiers in the intensive care unit. Chest 1990;97(1):144-149.

33. Misset B, Escudier B, Rivara D, Leclercq B, Nitenberg G. Heat and moisture exchangers vs heated humidifier during long term mechanical ventilation. Chest 1991;100(1):160-163. 
34. Roustan JP, Kienlen J, Aubas P, Aubas S, du Cailar J. Comparison of hydrophobic heat and moisture exchangers with heated humidifiers during prolonged mechanical ventilation. Intensive Care Med 1992;18(2):97-100.

35. Lellouche F, Taillé S, Maggiore SM, Qader S, L'Her E, Deye N, Brochard L. Influence of ambient and ventilator output temperatures on performance of heated-wire humidifiers. Am J Respir Crit Care Med 2004;170(10):1073-1079.

36. Beydon L, Tong D, Jackson N, Dreyfuss D. Correlation between simple clinical parameters and the in vitro humidification characteristics of filter heat and moisture exchangers. Chest 1997;112(3): 739-744.

37. Hess DR, Kallstrom TJ, Mottram CD, Myers TR, Sorenson HM, Vines DL, American Association for Respiratory Care. Care of the ventilator circuit and its relation to ventilator-associated pneumonia. Respir Care 2003;48(9):869-879.

38. Branson RD, Davis K Jr. Evaluation of 21 passive humidifiers according to the ISO 9360 standard: moisture output, dead space, and flow resistance. Respir Care 1996;41(8):736-743.

39. Medical Devices Directorate Evaluation. Department of Health, Scottish Office Home and Health Department, Welsh Office, and Department of Health and Social Services, Northern Ireland; London, 1994.

40. Unal N, Pompe JC, Holland WP, Gültuna I, Huygen PE, Jabaaij K, Ince $\mathrm{C}$, et al. An experimental set-up to test heat-moisture exchangers. Intensive Care Med 1995;21(2):142-148.

41. Ricard JD, Le Mière E, Markowicz P, Lasry S, Saumon G, Djedaïni $\mathrm{K}$, et al. Efficiency and safety of mechanical ventilation with a heat and moisture exchanger changed only once a week. Am J Respir Crit Care Med 2000;161(1):104-109.

42. Hess DR. And now for the rest of the story. Respir Care 2002; 47(6):696-699.

43. Branson RD, Davis K Jr, Campbell RS, Johnson DJ, Porembka DT. Humidification in the intensive care unit: prospective study of a new protocol utilizing heated humidification and a hygroscopic condenser humidifier. Chest 1993;104(6):1800-1805.

44. Villafane MC, Cinnella G, Lofaso F, Isabey D, Harf A, Lemaire F, Brochard L. Gradual reduction of endotracheal tube diameter during mechanical ventilation via different humidification devices. Anesthesiology 1996;85(6):1341-1349.

45. Boqué MC, Gualis B, Sandiumenge A, Rello J. Endotracheal tube intraluminal diameter narrowing after mechanical ventilation: use of acoustic reflectometry. Intensive Care Med 2004;30(12):2204-2209.

46. Shah C, and Kollef MH. Endotracheal tube intraluminal volume loss among mechanically ventilated patients. Crit Care Med 2004; 32(1):120-125.

47. Jaber S, Pigeot J, Fodil R, Maggiore S, Harf A, Isabey D, et al. Long-term effects of different humidification systems on endotracheal tube patency: evaluation by the acoustic reflection method. Anesthesiology 2004;100(4):782-788.

48. Wilson AM, Gray DM, Thomas JG. Increases in endotracheal tube resistance are unpredictable relative to duration of intubation. Chest 2009;136(4):1006-1113

49. Morán I, Cabello B, Manero E, Mancebo J. Comparison of the effects of two humidifier systems on endotracheal tube resistance. Intensive Care Med 2011;37(11):1773-1779.

50. Rumbak MJ, Walsh FW, Anderson WM, Rolfe MW, Solomon DA. Significant tracheal obstruction causing failure to wean in patients requiring prolonged mechanical ventilation: a forgotten complication of long-term mechanical ventilation. Chest 1999;115(4):1092-1095.

51. Kirton OC, Banner MJ, Axelrad A, Drugas G. Detection of unsuspected imposed work of breathing: case reports. Crit Care Med 1993;21(5):790-795.
52. Kirton OC, DeHaven CB, Morgan JP, Windsor J, Civetta JM. Elevated imposed work of breathing masquerading as ventilator weaning intolerance. Chest 1995;108(4):1021-1025.

53. Oto J, Imanaka H, Nakataki E, Ono R, Nishimura M. Potential inadequacy of automatic tube compensation to decrease inspiratory work load after at least 48 hours of endotracheal tube use in the clinical setting. Respir Care 2012;57(5):697-703.

54. Hess DR, Branson RD. Airway and suction equipment. In: Branson RD, Hess DR, Chatburn RL, editors. Respiratory Care Equipment. Philadelphia: Lippincott Williams \& Wilkins; 1999: 157-186.

55. American Association for Respiratory Care. AARC Clinical Practice Guidelines. Endotracheal suctioning of mechanically ventilated patients with artificial airways 2010. Respir Care 2010;55(6):758764.

56. Lomholt N. Design and function of tracheal suction catheters. Acta Anaesthesiol Scand 1982;26(1):1-3.

57. Shah S, Fung K, Brim S, Rubin BK. An in vitro evaluation of the effectiveness of endotracheal suction catheters. Chest. 2005;128(5): 3699-3704.

58. Witmer MT, Hess D, Simmons M. An evaluation of the effectiveness of secretion removal with the Ballard closed-circuit suction catheter. Respir Care 1991;36(8):844-848.

59. Carlon GC, Fox SJ, Ackerman NJ. Evaluation of a closed-tracheal suction system. Crit Care Med 1987;15(5):522-525.

60. Johnson KL, Kearney PA, Johnson SB, Niblett JB, MacMillan NL, McClain RE. Closed versus open tracheal suctioning: costs and physiologic consequences. Crit Care Med 1994;22(4):654-666.

61. Harshbarger SA, Hoffman LA, Zullo TG, Pinsky MR. Effects of a closed tracheal suction system on ventilatory and cardiovascular parameters. Am J Crit Care 1992;1(3):57-61.

62. Deppe SA, Kelly JW, Thoi LL, Chudy JH, Longfield RN, Ducey $\mathrm{JP}$, et al. Incidence of colonization, nosocomial pneumonia, and morality in critically ill patients using a Trach Care closed-suction system versus an open-suction system: prospective, randomized study. Crit Care Med 1990;18(12):1389-1393.

63. Cobley M, Atkins M, Jones PL. Environmental contamination during tracheal suction. Anaesthesia 1991;46(11):957-961.

64. Ritz R, Scott LR, Coyle MB, Pierson DJ. Contamination of a multiple-use suction catheter in a closed-circuit system compared to contamination of a disposable, single-use suction catheter. Respir Care 1986;31(11):1086-1091.

65. Kollef MH, Prentice S, Shapiro SD, Fraser VJ, Silver P, Trovillion E, et al. Mechanical ventilation with or without daily changes of in-line suction catheters. Am J Respir Crit Care Med 1997;156(2 Pt 1):466-472.

66. Cereda M, Villa F, Colombo E, Greco G, Nacoti M, Pesenti A. Closed system endotracheal suctioning maintains lung volume during volume-controlled mechanical ventilation. Intensive Care Med 2001;27(4):648-654.

67. Maggiore SM, Lellouche F, Pigeot J, Taille S, Deye N, Durrmeyer $\mathrm{X}$, et al. Prevention of endotracheal suctioning-induced alveolar derecruitment in acute lung injury. Am J Respir Crit Care Med 2003;167(9):1215-1224.

68. Freytag CC, Thies FL, König W, Welte T. Prolonged application of closed in-line suction catheters increases microbial colonization of the lower respiratory tract and bacterial growth on catheter surface. Infection 2003;31(1):31-37.

69. Combes P, Fauvage B, Oleyer C. Nosocomial pneumonia in mechanically ventilated patients, a prospective randomised evaluation of the Stericath closed suctioning system. Intensive Care Med 2000; 26(7):878-882.

70. Darvas JA, Hawkins LG. The closed tracheal suction catheter: 24 hour or 48 hour change? Aust Crit Care 2003;16(3):86-92. 


\section{Management of the Artificial Airway}

71. Stoller JK, Orens DK, Fatica C, Elliott M, Kester L, Woods J, et al. Weekly versus daily changes of in-line suction catheters: impact on rates of ventilator-associated pneumonia and associated costs. Respir Care 2003;48(5):494-499.

72. Zeitoun SS, de Barros AL, Diccini S. A prospective, randomized study of ventilator-associated pneumonia in patients using a closed vs. open suction system. J Clin Nurs 2003;12(4):484-489.

73. Maggiore SM, Iacobone E, Zito G, Conti C, Antonelli M, Proietti R. Closed versus open suctioning techniques. Minerva Anestesiol 2002;68(5):360-364.

74. El Masry A, Williams PF, Chipman DW, Kratohvil JP, Kacmarek RM. The impact of closed endotracheal suctioning systems on mechanical ventilator performance. Respir Care 2005;50(3):345-353.

75. Morrow BM. Closed-system suctioning: why is the debate still open? Indian J Med Sci 2007;61(4):177-178.

76. Caramez MP, Schettino G, Suchodolski K, Nishida T, Harris RS, Malhotra A, Kacmarek RM. The impact of endotracheal suctioning on gas exchange and hemodynamics during lung-protective ventilation in acute respiratory distress syndrome. Respir Care 2006; 51(5):497-502.

77. Åkerman E, Larsson C, Ersson A. Clinical experience and incidence of ventilator-associated pneumonia using closed versus open suction-system. Nurs Crit Care 2014;19(1):34-41.

78. Lasocki S, Lu Q, Sartorius A, Fouillat D, Remerand F, Rouby JJ. Open and closed-circuit endotracheal suctioning in acute lung injury: efficiency and effects on gas exchange. Anesthesiology 2006; 104(1):39-47.

79. Adi NA, Tomer NT, Bergman GB, Kishinevsky EK, Wyncoll DW. Effects of prolonged mechanical ventilation with a closed suction system on endotracheal tube resistance and its reversibility by a closed suction cleaning system. Anaesth Intensive Care 2013;41(6): 728-735.

80. Corley A, Sharpe N, Caruana LR, Spooner AJ, Fraser JF. Lung volume changes during cleaning of closed endotracheal suction catheters: a randomised crossover study using electrical impedance tomography. Respir Care 2014;59(4)497-503.

81. Anthony JS, Sieniewicz DJ. Suctioning of the left bronchial tree in critically ill patients. Crit Care Med 1977;5(3):161-162.

82. Panacek EA, Albertson TE, Rutherford WF, Fisher CJ, Foulke GE. Selective left endobronchial suctioning in the intubated patient. Chest 1989;95(4):885-887.

83. Haberman PB, Green JP, Archibald C, Dunn DL, Hurwitz SR, Ashburn WL, Moser KM. Determinants of successful selective tracheobronchial suctioning. N Engl J Med 1973;289(20):1060-1063.

84. Spence K, Gillies D, Waterworth L. Deep versus shallow suction of endotracheal tubes in ventilated neonates and young infants. Cochrane Database Syst Rev 2003;(3):CD003309.

85. Ahn Y, Hwang T. The effects of shallow versus deep endotracheal suctioning on the cytological components of respiratory aspirates in high risk infants. Respiration 2003;70(2):172-178.

86. Van de Leur JP, Zwaveling JH, Loef BG, Van der Schans CP. Patient recollection of airway suctioning in the ICU: routine versus a minimally invasive procedure. Intensive Care Med 2003;29(3): 433-436.

87. Van de Leur JP, Zwaveling JH, Loef BG, Van der Schans CP. Endotracheal suctioning versus minimally invasive airway suctioning in intubated patients: a prospective randomised controlled trial. Intensive Care Med 2003;29(3):426-432.

88. Celik SA, Kanan N. A current conflict: use of isotonic sodium chloride solution on endotracheal suctioning in critically ill patients. Dimens Crit Care Nurs 2006;25(1):11-14.

89. Ridling DA, Martin LD, Bratton SL. Endotracheal suctioning with or without instillation of isotonic sodium chloride solution in critically ill children. Am J Crit Care 2003;12(3):212-219.
90. Akgül S, Akyolcu N. Effects of normal saline on endotracheal suctioning. J Clin Nurs 2002;11(6):826-830.

91. Raymond SJ. Normal saline instillation before suctioning: helpful or harmful? A review of the literature. Am J Crit Care 1995;4(4): 267-271.

92. Ji YR, Kim HS, Park JH. Instillation of normal saline before suctioning in patients with pneumonia. Yonsei Med J 2002;43(5):607612.

93. Shorten DR, Byrne PJ, Jones RL. Infant responses to saline instillations and endotracheal suctioning. J Obstet Gynecol Neonatal Nurs 1991;20(6):464-469.

94. Blackwood B. Normal saline instillation with endotracheal suctioning: primum non nocere (first do no harm). J Adv Nurs 1999;29(4): 928-934.

95. Ackerman MH, Ecklund MM, Abu-Jumah M. A review of normal saline instillation: implications for practice. Dimens Crit Care Nurs 1996;15(1):31-38

96. Hagler DA, Traver GA. Endotracheal saline and suction catheters: sources of lower airway contamination. Am J Crit Care 1994;3(6): 444-447.

97. Druding MC. Re-examining the practice of normal saline instillation prior to suctioning. Medsurg Nurs 1997;6(4):209-212.

98. Ackerman MH. The effect of saline lavage prior to suctioning. Am J Crit Care 1993;2(4):326-330.

99. Ninan A, O’Donnell M, Hamilton K, Tan L, Sankaran K. Physiologic changes induced by endotracheal instillation and suctioning in critically ill preterm infants with and without sedation. Am J Perinatol 1986;3(2):94-97.

100. Schwenker D, Ferrin M, Gift AG. A survey of endotracheal suctioning with instillation of normal saline. Am J Crit Care 1998; 7(4):255-260.

101. Bostick J, Wendelgass ST. Normal saline instillation as part of the suctioning procedure: effects on $\mathrm{PaO} 2$ and amount of secretions. Heart Lung 1987;16(5):532-537.

102. Ackerman MH, Mick DJ. Instillation of normal saline before suctioning in patients with pulmonary infections: a prospective randomized controlled trial. Am J Crit Care 1998;7(4):261-266.

103. Morrow BM, Futter MJ, Argent AC. Endotracheal suctioning: from principles to practice. Intensive Care Med 2004;30(6):1167-1174.

104. Gray JE, MacIntyre NR, Kroneenberger WG. The effects of bolus normal-saline instillation in conjunction with endotracheal suctioning. Respir Care 1990;35(8):785-790.

105. Seckel MA. Normal saline and mucus plugging. Crit Care Nurse 2012;32(5):66-68.

106. Jubran A, Tobin MJ. Use of flow-volume curves in detecting secretions in ventilator-dependent patients. Am J Respir Crit Care Med 1994;150(3):766-769.

107. Guglielminotti J, Alzieu M, Maury E, Guidet B, Offenstadt G. Bedside detection of retained tracheobronchial secretions in patients receiving mechanical ventilation: is it time for tracheal suctioning? Chest 2000;118(4):1095-1099.

108. Zamanian M, Marini JJ. Pressure-flow signatures of central-airway mucus plugging. Crit Care Med 2006;34(1):223-226.

109. Visaria RK, Westenskow D. Model-based detection of partially obstructed endotracheal tube. Crit Care Med 2005;33(1):149-154; discussion 249-50.

110. Maggiore SM, Lellouche F, Pignataro C, Girou E, Maitre B, Richard JC, et al. Decreasing the adverse effects of endotracheal suctioning during mechanical ventilation by changing practice. Respir Care 2013;58(10):1588-1597.

111. Kolobow T, Li Bassi G, Curto F, Zanella A. The Mucus Slurper: a novel tracheal tube that requires no tracheal tube suctioning. A preliminary report. Intensive Care Med 2006;32(9):1414-1418. 
112. Li Bassi G, Curto F, Zanella A, Stylianou M, Kolobow T. A 72hour study to test the efficacy and safety of the "Mucus Slurper" in mechanically ventilated sheep. Crit Care Med 2007;35(3):906-911.

113. Kolobow T, Berra L, Li Bassi G, Curto F. Novel system for complete removal of secretions within the endotracheal tube: the Mucus Shaver. Anesthesiology 2005;102(5):1063-1065.

114. Berra L, Coppadoro A, Bittner EA, Kolobow T, Laquerriere P, Pohlmann JR, et al. A clinical assessment of the Mucus Shaver: a device to keep the endotracheal tube free from secretions. Crit Care Med 2012;40(1):119-124.

115. Balazs DJ, Triandafillu K, Wood P, Chevolot Y, van Delden C, Harms $\mathrm{H}$, et al. Inhibition of bacterial adhesion on PVC endotracheal tubes by RF-oxygen glow discharge, sodium hydroxide and silver nitrate treatments. Biomaterials 2004;25(11):2139-2151.

116. Hollinger MA. Toxicological aspects of topical silver pharmaceuticals. Crit Rev Toxicol 1996;26(3):255-260.

117. Jansen B, Kohnen W. Prevention of biofilm formation by polymer modification. J Ind Microbiol 1995;15(4):391-396.

118. Kumon H, Hashimoto H, Nishimura M, Monden K, Ono N. Catheter-associated urinary tract infections: impact of catheter materials on their management. Int J Antimicrob Agents 2001;17(4):311-316.

119. Olson ME, Harmon BG, Kollef MH. Silver-coated endotracheal tubes associated with reduced bacterial burden in the lungs of mechanically ventilated dogs. Chest 2002;121(3):863-870.

120. Rello J, Kollef M, Diaz E, Sandiumenge A, del Castillo Y, Corbella $\mathrm{X}$, Zachskorn R. Reduced burden of bacterial airway colonization with a novel silver-coated endotracheal tube in a randomized multiple-center feasibility study. Crit Care Med 2006;34(11):2766-2772.

121. Raad II, Mohamed JA, Reitzel RA, Jiang Y, Dvorak TL, Ghannoum MA, et al. The prevention of biofilm colonization by multidrug resistant pathogens that cause ventilator associated pneumonia and antimicrobial coated endotracheal tubes. Biomaterials 2011; 32(11):2689-2694

122. Berra L, De Marchi L, Yu ZX, Laquerriere P, Baccarelli A, Kolobow T. Endotracheal tubes coated with antiseptics decrease bacterial colonization of the ventilator circuits, lungs, and endotracheal tube. Anesthesiology 2004;100(6):1446-1456.

123. Berra L, Curto F, Li Bassi G, Laquerriere P, Pitts B, Baccarelli A, Kolobow T. Antimicrobial coated endotracheal tubes: an experimental study. Intensive Care Med 2008;34(6):1020-1029.

124. Berra L, Curto F, Li Bassi G, Baccarelli A, Lolobow T. Antibacterial coated tubes cleaned with the Mucus Shaver: a novel method to retain long term bactericidal activity of coated tracheal tubes. Intensive Care Med 2006;32(6):888-893.

125. Biel MA, Sievert C, Usacheva M, Teichert M, Wedell E, Loebel N, et al. Reduction of endotracheal tube biofilms using antimicrobial photodynamic therapy. Lasers Surg Med 2011;43(7):586-590.

126. Nacheli GC, Sharma M, Wang X, Gupta A, Guzman JA, Tonelli AR. Novel device (AirWave) to assess endotracheal tube migration: a pilot study. J Crit Care 2013;28(4):535.e1-535.e8

127. Wang ML, Schuster KM, Bhattacharya B, Maung AA, Kaplan LJ, Davis KA. Repositioning endotracheal tubes in the intensive care unit: depth changes poorly correlate with postrepositioning radiographic location. J Trauma Acute Care Surg 2013;75(1):146-149.
128. Stone RH, Bricknell SS. Experience with a new device for clearing mucus form the endotracheal tube. Respir Care 2011;56(4):520-522.

129. Mietto C, Foley K, Slaerno L, Oleksak J, Pinciroli R, Gverman J, Berra L. Removal of endotracheal tube debris obstruction by a clearing secretion device. Respir Care 2013 [Epub ahead of print] doi:10.4187/respcare.02995

130. Kacmarek RM. Efficacy study of a novel device to clean the endotracheal tube. ClinicalTrials.gov identifier NCT01765530. http:// clinicaltrials.gov/show/NCT01765530.

131. Guyton D, Banner MJ, Kirby RR. High-volume, low-pressure cuffs. Are they always low pressure? Chest 1991;100(4):1076-1081.

132. Sole ML, Su X, Talbert S, Penoyer DA, Kalita S, Jimenez E, et al. Evaluation of an intervention to maintain endotracheal tube cuff pressure within therapeutic range. Am J Crit Care 2011;20(2):109-117.

133. Rello J, Soñora R, Jubert P, Artigas A, Rué M, Vallés J. Pneumonia in intubated patients: role of respiratory airway care. Am J Respir Crit Care Med 1996;154(1):111-115.

134. Rouzé A, Nseir S. Continuous control of tracheal cuff pressure for the prevention of ventilator associated pneumonia in critically ill patients: where is the evidence? Curr Opin Crit Care 2013;19(5): 440-447.

135. Howard WR. Bench study of a new device to display and maintain stable artificial airway cuff pressure. Respir Care 2011;56(10):15061513.

136. Kunitz O, Jansen R, Ohnsorge E, Haaf-vonBelow S, Schulz-Stübner S, Rossaint R. Cuff pressure monitoring and regulation in adults. Anaesthesist 2004;53(4):334-340.

137. Farré R, Rotger M, Ferrer M, Torres A, Navajas D. Automatic regulation of cuff pressures in endotracheally-intubated patients. Eur Respir J 2002;20(4):1010-1013.

138. Nseir S, Duguet A, Copin MC, De Jonckheere J, Zhang M, Similowski T, Marquette $\mathrm{CH}$. Continuous control of endotracheal cuff pressure and tracheal wall damage: a randomized controlled animal study. Crit Care 2007;11(5):R109.

139. Valencia M, Ferrer M, Farré R, Navajas D, Badia JR, Nicolas JM, Torres A. Automatic control of tracheal tube cuff pressure in ventilated patients in semirecumbent position: a randomized trial. Crit Care Med 2007;35(6):1543-1549.

140. Nseir S, Zerimech F, Fournier C, Lubret R, Ramon P, Durocher A, Balduyck M. Continuous control of tracheal cuff pressure and microaspiration of gastric contents in critically ill patients. Am J Respir Crit Care Med 2011;184(9):1041-1047.

141. Jaillette E, Zemrich F, De Honckheere J, Makris D, Balduyck M, Durocher A. Efficiency of a pneumatic device in controlling cuff pressure of poly urethane cuffed tracheal tubes: a randomized controlled study. BMC Anesthesiol 2013;13:50.

142. Weiss M, Doell C, Koepfer N, Madjdpour C, Woitzek K, Bernet V. Rapid pressure compensation by automated cuff pressure controllers worsens sealing in tracheal tubes. Brit J Anaesth 2009;102(2):273-278.

143. Brisson H, Bouhemad B, Lu Q, Rouby JJ. Comparison of two automated endotracheal cuff pressure regulators devices in intubated critically ill patients: mechanical and electronic. 24th ESICM Annual Congress, October 1-5, 2011, Berlin, Germany. http://posterconsultation.esicm.org/moduleconsultationposter/posterdetail.aspx?in tidposter $=2833$

\section{Discussion}

Durbin: I was intrigued by all the reports of the ultrasonic evaluation of tube narrowing, but I've never seen anyone describe what happens if the tube is kinked or bent. It seems to me like that might confuse the device into thinking there is a problem with secretions. What if the tube is only curved as opposed to narrowed? Any thoughts on that? Have you seen any 
thing about how these devices behave under anything but ideal circumstances?

Branson: The device can tell if the tube kinks, but I don't know if it can tell the difference between the tube kinking and the tube having secretions causing the narrowing. Again, interesting idea, but presently there are no clinical data for us to make any assessments.

Durbin: Using the rescue devices routinely for cleaning the tube would involve breaking the circuit to use them. Any thoughts about how much benefit in preventing VAEs [ventilator-associated events] you would loose by doing that? Obviously, in a selected patient who's having a particular problem where you think it might be helpful, it would be appropriate and justifiable to break the circuit. If you're doing it in a routine cleaning-maintenance program, do you have to break the circuit? Can you put the device in through a plug or anything like that? Is there something like the continuous inline suction systems, or are you necessarily increasing risk by passing something that's outside the patient into the airway?

Branson: My experience is you have to take the patient off, otherwise you can't pull the device out. Dean, are they doing it with some kind of closed system like a bronch adapter or just opening the circuit?

Hess: For the endOclear device, there is an adapter that goes inline, so the circuit needs to be opened to insert that. The device feeds through that adapter to a premeasured length, so it doesn't go past the tip of the endotracheal tube. It is a blind procedure.
Davies: What do they do with the secretions? Is there some sort of collector attached to the adapter? Because when you pull it out, the secretions have to go someplace.

Hess: For this one, there is no suction as part of it.

Napolitano: It could go down, too, though, right?

Davies: So how do you get the crud off the device?

Hess: It has a mesh-like wiper design. I have equipoise regarding its effect on important outcomes such as VAP [ventilator-associated pneumonia] rate. The real value, I think, is in a patient with a suggestion of an endotracheal tube occlusion. We have used it a few times with good success as a rescue, using it rather than reintubating the patient.

Branson: John, it's a single use, so you put it in the trash when you're done. The whole thing, the catheter, gets thrown away.

Davies: So you have to break the circuit every time you use it?

Hess: Yes.

Durbin: What's the role of bronchodilators in airway management in the absence of overt asthma?

Branson: Don't use them. The ARDSNet group did a study on $\beta$ agonists ${ }^{1}$ and found that the patients who got albuterol with no indications did worse. It is a real-world problem. In our surgical ICU, the therapists, if the patient's on the ventilator, they'll say, 'the patient has a history of COPD,' and I'll say 'what does that mean?'
Somebody wrote it in a chart, they smoke, what is the source of the information? In my opinion, we give a lot of bronchodilators that don't need to be given to mechanically ventilated patients.

Haas: About the automated systems, one thing that kept coming up as I was reading is the reduced ability of the cuff to self-seal when using the automated systems. You alluded to it in coughing where pressures really go up, and then, in essence, the internal pressure in an automated system would be reduced. Is it just during coughing or is that a concern in clinical management with the automated system?

Branson: I think it's a concern with high airway pressures with every mandatory breath; I think cuff pressures can change markedly in patients who are turning in a bed that's moving and in patients who are prone. I think of all the things we do to patients and repositioning the tube that affects the cuff pressure, and I think they're realworld problems. Like I said, it may be that a faster cuff pressure response may not be better. They may need to be more aggressive at going up than going down, and look at a mean value as opposed to doing instantaneous changes and maintain a pressure constant.

\section{REFERENCES}

1. National Heart, Lung, and Blood Institute Acute Respiratory Distress Syndrome (ARDS) Clinical Trials Network, Matthay MA, Brower RG, Carson S, Douglas IS, Eisner M, et al. Randomized, placebo-controlled clinical trial of an aerosolized $\beta_{2}$ agonist for treatment of acute lung injury. Am J Respir Crit Care Med 2011;184(5): 561-568. 